\title{
Kontaminasi Bakteri Pada Saus Tomat Mie Ayam di Pasar Condong Catur Sleman Yogyakarta Tahun 2013
}

\author{
FITRI NADIFAH ${ }^{1}$, MARIA YASINTHA BHOGA ${ }^{1}$, YULIANA PRASETYANINGSIH ${ }^{1}$ \\ ${ }^{1}$ Program Studi D3 Analis Kesehatan STIKES Guna Bangsa Yogyakarta \\ Jl. Ring Road Utara, Sleman, Daerah Istimewa Yogyakarta 55283 \\ email: fitri.nadifah@gmail.com
}

\begin{abstract}
The tomato sauce is a complementary food that is often served with other foods, such as chicken noodles. Various factors can be the cause of contamination of tomato sauce by microbes like bacteria. These factors include environmental conditions that are not clean or container that was left open. Bacterial contamination in tomato sauce can result not suitable for consumption. Given by the high public interest in the consumption of tomato sauce with chicken noodle, it is necessary to observe the bacterial contamination of chicken noodle tomato sauce. To determine the bacterial contamination in tomato sauce of chicken noodle in traditional market of Condong Catur, Sleman, Yogyakarta. The samples used were tomato sauces that are used by chicken noodle stalls in the Condong Catur traditional market. Sampling was also carried out by recording the environmental conditions stalls and tomato sauce serving. To determine the bacterial contamination, samples examined in the laboratory based on the total bacterial count method using plate count agar (PCA) media. Seven of the ten samples showed the total number of bacteria $<10^{4} \mathrm{CFU} / \mathrm{ml}$, whereas the other three samples are not suitable for consumption by the total number of bacteria $>10^{4} \mathrm{CFU} / \mathrm{ml}$. The main factors of high contamination is poor hygiene of chicken noodle stall environmental, tomato sauce containers that are less clean and are often left open.
\end{abstract}

Keywords: tomato sauce, total bacteria

\section{PENDAHULUAN}

Saus tomat adalah makanan pelengkap bentuk pasta yang sering disajikan bersama dengan makanan lain, seperti mie ayam. Saus tomat pada dasarnya adalah produk yang dapat bertahan lama karena $\mathrm{pH}$ produk yang rendah, penambahan asam benzoat dan perlakuan pemanasan saat proses produksi. Namun proses produksi saus tomat yang tidak memenuhi standar dapat mengakibatkan kontaminasi mikroba pada saus tomat maupun botol kemasan (Bjorkroth and Korkeala, 1997).

Dalam keadaan tertutup rapat, saus tomat dapat terlindung dari segala pengaruh yang berasal dari luar seperti mikrobia penyebab kebusukan. Tetapi apabila dibiarkan terbuka, maka akan meningkatkan resiko kontaminasi saus tomat oleh mikroba, seperti bakteri. Saus tomat akan menjadi media yang sangat disukai oleh bakteri untuk tumbuh dan berkembangbiak. Salmonella, Bacillus, dan Enterobacter adalah contoh genus bakteri pengkontaminasi makanan yang dapat mengancam atau membahayakan kesehatan manusia (Siagian, 2002).

Penelitian yang dilakukan oleh Mansauda dkk (2014) menunjukkan bahwa 12 sampel saus tomat jajanan bakso tusuk di Manado terkontaminasi oleh bakteri coliform dan Escherichia coli. Hasil penelitian Bjorkroth and Korkeala (1997) menemukan adanya kontaminasi bakteri Lactobacillus fructivorans pada botol saus tomat. Selain bakteri, ditemukan pula berbagai spesies jamur seperti Alternaria alternate, Aspergillus foetidus dan Rhizopus oryzae (Kalyoncu et al., 2005). Kontaminasi oleh bakteri dapat menyebabkan menurunnya mutu mikrobiologis saus tomat. Penurunan mutu mikrobiologis dapat mengakibatkan saus tomat menjadi tidak layak dikonsumsi karena cemaran mikroba yang di atas ambang batas (Gea 2009). Kondisi lingkungan yang tidak memadai, ditambah praktik penjualan yang kurang bersih sangat memungkinkan 
terjadinya kontaminasi mikroba patogen (Hartati, 2012).

Badan Pengawas Obat dan Makanan, selama kurun waktu 2008-2012 melaporkan telah terjadi kurang lebih 687 kejadian luar biasa (KLB) keracunan pangan yang berarti frekuensi rata-rata kejadian sekitar 137 kali per tahun di Indonesia (Nababan, 2014). Mengingat tingginya minat masyarakat dalam mengonsumsi saus tomat bersama dengan mie ayam, maka perlu dilakukan penelitian untuk mengetahui gambaran kontaminasi bakteri pada saus tomat mie ayam di Pasar Condong Catur, Sleman, Yogyakarta.

\section{METODE}

Peneliti mengambil sampel saus tomat dari sepuluh warung mie ayam. Selain itu dilakukan pula survey mengenai kondisi dan tempat penyajian saus tomat, serta kondisi warung mie ayam itu sendiri. Indikator yang dicatat meliputi kondisi botol, warna, bau, lokasi warung dari tempat pembuangan sampah, dan bintik-bintik hitam pada saus tomat.

Untuk mengetahui angka kuman pada sampel saus tomat, dilakukan pengenceran 10$10^{4}$. Dari tiap pengenceran tersebut diambil 1 $\mathrm{ml}$ kemudian dituang dalam cawan petri. Sebagai kontrol, digunakan $\mathrm{NaCl}$ 0,85\%. Masing-masing cawan petri yang telah berisi sampel dan $\mathrm{NaCl}$ dituangi dengan plate count agar. Inkubasi dilakukan pada suhu $37^{\circ} \mathrm{C}$ selama 48 jam. Perhitungan koloni bakteri dilakukan secara manual pada tiap pengenceran, baik koloni besar maupun kecil. Pengenceran sampel dilakukan untuk memudahkan dalam menghitung angka kuman. Idealnya jumlah koloni tiap cawan berkisar antara 30-300 (Colony Forming Unit) $\mathrm{CFU} / \mathrm{ml}$.

Hasil pemeriksaan dinyatakan dengan jumlah koloni yang tumbuh pada cawan permilimeter sampel yang asli.

\section{HASIL}

Penelitian ini menggunakan sepuluh sampel saus tomat yang terdiri atas 4 merek yang berbeda. Dari sepuluh sepuluh sampel tersebut, seluruhnya tidak terdapat bintikbintik hitam, tidak berbau dan tidak berubah warna. Hal ini menandakan bahwa saus tomat yang disajikan masih dalam kondisi fisik yang baik. Walaupun saat disajikan saus tomat terlihat bersih, tetapi seringkali wadah saus dibiarkan dalam keadaan terbuka. Kondisi inilah yang menyebabkan semakin tinggi resiko kontaminasi saus tomat oleh mikroba.

Kemasan asli sampel A, B, C, F, G, H dan $\mathrm{J}$ adalah plastik. Dari kemasan plastik tersebut kemudian saus dipindahkan ke dalam botol plastik serta disimpan dalam keadaan tertutup dan bersih, botol saus selalu dicuci menggunakan air bersih sebelum digunakan kembali. Sampel A, B, C, F, G, H dan J adalah saus murni tidak dicampur dengan air, lokasi warung jauh dari tempat pembuangan sampah sehingga tidak mudah terkontaminasi mikroba.

Tabel 1. Hasil pemeriksaan sampel saus tomat

\begin{tabular}{|c|c|c|c|c|c|c|c|}
\hline \multirow[t]{2}{*}{ S } & \multirow{2}{*}{$\begin{array}{c}\mathrm{AK} \\
(\mathrm{CFU} / \mathrm{ml})\end{array}$} & \multicolumn{6}{|c|}{ Indikator } \\
\hline & & I & II & III & IV & V & VI \\
\hline A & 453 & $\sqrt{ }$ & $\sqrt{ }$ & $\sqrt{ }$ & $\sqrt{ }$ & $\sqrt{ }$ & $\sqrt{ }$ \\
\hline B & 2.733 & $\sqrt{ }$ & $\sqrt{ }$ & $\sqrt{ }$ & $\sqrt{ }$ & $\sqrt{ }$ & $\sqrt{ }$ \\
\hline $\mathrm{C}$ & 2.966 & $\sqrt{ }$ & - & $\sqrt{ }$ & $\sqrt{ }$ & $\sqrt{ }$ & - \\
\hline $\mathrm{D}$ & 10.600 & - & - & $\sqrt{ }$ & $\sqrt{ }$ & - & - \\
\hline $\mathrm{E}$ & 12.533 & - & - & $\sqrt{ }$ & - & - & - \\
\hline $\mathrm{F}$ & 353 & - & $\sqrt{ }$ & $\sqrt{ }$ & $\sqrt{ }$ & $\sqrt{ }$ & $\sqrt{ }$ \\
\hline G & 2.733 & $\sqrt{ }$ & $\sqrt{ }$ & $\sqrt{ }$ & $\sqrt{ }$ & $\sqrt{ }$ & $\sqrt{ }$ \\
\hline $\mathrm{H}$ & 2.700 & $\sqrt{ }$ & $\sqrt{ }$ & $\sqrt{ }$ & $\sqrt{ }$ & $\sqrt{ }$ & $\sqrt{ }$ \\
\hline I & 23.333 & - & - & - & - & - & - \\
\hline $\mathrm{J}$ & 1.146 & $\sqrt{ }$ & $\sqrt{ }$ & $\sqrt{ }$ & $\sqrt{ }$ & $\sqrt{ }$ & $\sqrt{ }$ \\
\hline
\end{tabular}


Keterangan:

$(\sqrt{ })$ : Ya; (-): Tidak; S: Sampel; I: Botol saus tomat yang digunakan tertutup; II: Botol dicuci dengan air bersih; III: Saus tomat tidak terjadi perubahan warna; IV: Saus tomat tidak berbau; V: Lokasi warung jauh dari tempat pembuangan sampah; VI: Saus tomat tidak terdapat bintik-bintik hitam.

\section{PEMBAHASAN}

Berdasarkan Standar Nasional Indonesia (SNI) saus tomat No.7338-2009, jumlah maksimal cemaran mikroba pada saus tomat adalah $1 \times 10^{4}$ (Badan Standarisasi Nasional, 20014). Dari hasil pemeriksaan, diketahui bahwa 30\% sampel (D, E dan I) tidak layak konsumsi dengan angka kuman $>10^{4} \mathrm{CFU} / \mathrm{ml}$. Sedangkan angka kuman sampel A, B,C, F , G, $\mathrm{H}$ dan $\mathrm{J}$ masih di bawah ambang batas cemaran mikroba, yaitu $<10^{4} \mathrm{CFU} / \mathrm{ml}$ (Tabel 1).

Sampel I disajikan dalam botol yang kurang bersih dan dibiarkan terbuka, saus yang disajikan dicampur air, wadah penyimpanan saus tidak dicuci sebelum digunakan kembali, lokasi warungnya dekat dengan pembuangan sampah yang mengakibatkan mudah terkontaminasi mikroba. Bahan pangan yang dikonsumsi harus memenuhi syarat, antara lain: memiliki nilai gizi, menarik (warna dan tekstur) serta bebas dari bahan-bahan berbahaya seperti cemaran kimia, mikroba dan sebagainya (Saparinto dkk, 2006). Bahan pangan dapat berperan sebagai substrat untuk pertumbuhan mikroorganisme patogen penyebab penyakit (Siagian, 2002). Penjual mie ayam yang menggunakan saus tomat disarankan untuk lebih memperhatikan kebersihan, termasuk selalu menyajikan saus tomat dengan wadah dalam kondisi tertutup. Apabila wadah dibiarkan terbuka sangat memungkinkan pertumbuhan mikroba patogen, seperti parasit dan bakteri.

Kontaminasi makanan oleh mikroba patogen, seperti pada saus tomat, dapat menyebabkan gangguan-gangguan kesehatan pada konsumen. Untuk mengurangi resiko infeksi penyakit bagi konsumen, maka perlu diperhatikan beberapa hal antara lain sanitasi dan kebersihan warung, higiene makanan, penyimpanan makanan secara tepat dan benar, mencuci tangan sebelum menjamah makanan, dan lebih memperhatikan perubahan fisik yang terjadi pada saus tomat tersebut.
Hasil penelitian ini menunjukkan bahwa Pemerintah dan Pemerintah Daerah bersama dengan instansi yang terkait masih perlu melakukan pengawasan makanan terhadap saus tomat yang banyak dikonsumsi masyarakat sesuai dengan pasal 68 UU No. 18 Tahun 2012 tentang Pangan. Pengawasan makanan, seperti pada saus tomat bertujuan untuk melindungi masyarakat konsumen terhadap kemungkinan peredaran makanan yang tidak memenuhi standar dan persyaratan kesehatan yang dapat merugikan atau membahayakan kesehatan. Meskipun sampel diambil dari satu pasar tradisional di Sleman, namun merek saus tomat yang diperiksa adalah saus tomat yang beredar di Yogyakarta. Hasil penelitian ini dapat memberikan gambaran tentang kontaminasi bakteri pada saus tomat.

\section{KESIMPULAN}

Tiga dari sepuluh sampel saus tomat yang diperiksa tidak layak konsumsi dengan angka kuman $>10^{4} \mathrm{CFU} / \mathrm{ml}$. Beberapa faktor penyebab tingginya kontaminasi saus tomat adalah kondisi kebersihan warung mie ayam yang kurang terjaga, wadah saus tomat yang jarang dibersihkan dan seringkali dibiarkan dalam kondisi terbuka.

\section{DAFTAR PUSTAKA}

Bjorkroth KJ and Korkeala HJ. 1997. Lactobacillus fructivorans Spoilage of Tomato Ketchup. Journal of Food Protection. vol 60 (5): 1.

Gea SI. 2009. Hygiene Sanitasi dan Analisa Cemaran Mikroba yang Terdapat pada Saus Tomat dan Saus Cabe Isi Ulang yang digunakan di Kantin di Lingkungan Universitas Sumatera Utara Tahun 2009. [Skripsi]. Medan: Fakultas Kesehatan Masyarakat. Universitas Sumatera Utara.

Hartati AS. 2012. Dasar-dasar Mikrobiologi Kesehatan. Yogyakarta: Penerbit Nuha Medika. 
Kalyoncu FA, Tamer U and Oskay M. 2005. Determination of Fungi Associated with Tomatoes (Lycopersicum esculentum M.) and Tomato Pastes. Plant Pathology. vol 4: 146-149.

Mansauda KLR, Fatimawati dan Kojong N. 2014. Analisis Cemaran Bakteri Coliform pada Saus Tomat Jajanan Bakso Tusuk yang Beredar di Manado. Jurnal Ilmiah Farmasi Universitas Sam Ratulangi. vol 3 (2): 110.
Nababan. 2014. Catatan Keamanan Pangan Indonesia Menjelang MEA 2014. Jakarta: Food Review Indonesia edisi Mei 2014.

Saparinto, Cahyo dan Hidayati D. 2006. Bahan Tambahan Pangan. Yogyakarta: Penerbit Kanisius.

Siagian A. 2002. Mikroba Patogen pada Makanan dan Sumber Pencemarannya. Medan: Universitas Sumatera Utara Digital Library. 